\title{
Geochemistry of Ordovician volcanic rocks of the Tetagouche Group of southwestern New Brunswick
}

\author{
J. Dostal \\ Department of Geology, Saint Mary's University, Halifax, Nova Scotia B3H 3C3, Canada
}

Date Received July 25, 1989

Date Accepted September 29, 1989

\begin{abstract}
The Lower to Middle Ordovician volcanic suite of the Tetagouche Group from the southwestern part of the Miramichi Terrane in the Woodstock-Meductic area in southwestern New Brunswick is composed of a bimodal basalt-rhyolite association. The basalts have calc-alkalic char acter istics and were emplaced on the continental crust in a volcanic arc or back-arc environment. The rhyolites were probably derived by melting of an amphibolite-facies crust. The basalts differ from those of the Tetagouche Group from the Bathurst area which include within-plate basalts and MORB. However, they both may be part of a single Ordovician arc-back-arc system.
\end{abstract}

Le cortège volcanique du Groupe de Tétagouche (Ordovicien médian à inférieur) dans la portion sud-ouest de la Lanière de Miramichi (région de Woodstock-Meductic, sud-ouest du Nouveau-Brunswick) se compose d'une association bimodale de basalte et rhyolite. Les basaltes présentent des caractères calco-alcalins et ils se sont mis en place sur la croûte continentale dans un milieu d'arc insulaire ou de rétro-arc. Les rhyolites proviennent probablement de la fonte d'une croûte de faciès à amphibolites. Les basaltes different de ceux du Groupe de Tétagouche dans la région de Bathurst, qui comprennent des basaltes intra-plaques et des MORB, quoique tous deux puissent faire partie d'un système arc:rétro-arc ordovicien unique.

[Traduit par le joumal]

\section{INTRODUCTION}

The Miramichi Terrane (or Miramichi Anticlinorium of Rodgers, 1970) of the Canadian Appalachians is one of the distinct tectonostratigraphic zones of pre-Carboniferous strata in New Brunswick (Ruitenberg et al., 1977; Fyffe and Fricker, 1987). It constitutes a northeast-trending belt, usually $10-40 \mathrm{~km}$ wide, across New Brunswick (Fig. 1). The Miramichi Terrane is composed predominantly of the Cambro-Ordovician Tetagouche Group, a volcano-sedimentary sequence containing a voluminous bimodal suite of basaltic and rhyolitic rocks. In northern New Brunswick, the volcanic rocks have been used previously for interpreting the tectonic setting of the Miramichi Terrane and formulating various plate tectonic models of the early evolution of the northern Appalachians (Rast and Stringer, 1974; Pajari et al., 1977; Whitehead and Goodfellow, 1978; van Staal, 1987). The sequence has been correlated with comparable units in Maine (Neuman, 1968, 1984; Roy and Mencher, 1976; van Staal, 1987) and Newfoundland (Rast et al., 1976; Fyffe, 1982; van Staal, 1987) and with amphibolite-facies metamorphic rocks of the Miramichi Highlands in New Brunswick (Fyffe et al., 1988). In the Bathurst area of northeastern New Brunswick, volcanic rocks of the Tetagouche Group host many massive sulphide deposits including one of the world's largest lead-zinc producers, the Brunswick No. 12 orebody.
Rocks considered to be Tetagouche correlatives crop out in the southern part of the Miramichi Terrane. However, no geochemical data are available on the volcanic rocks from this

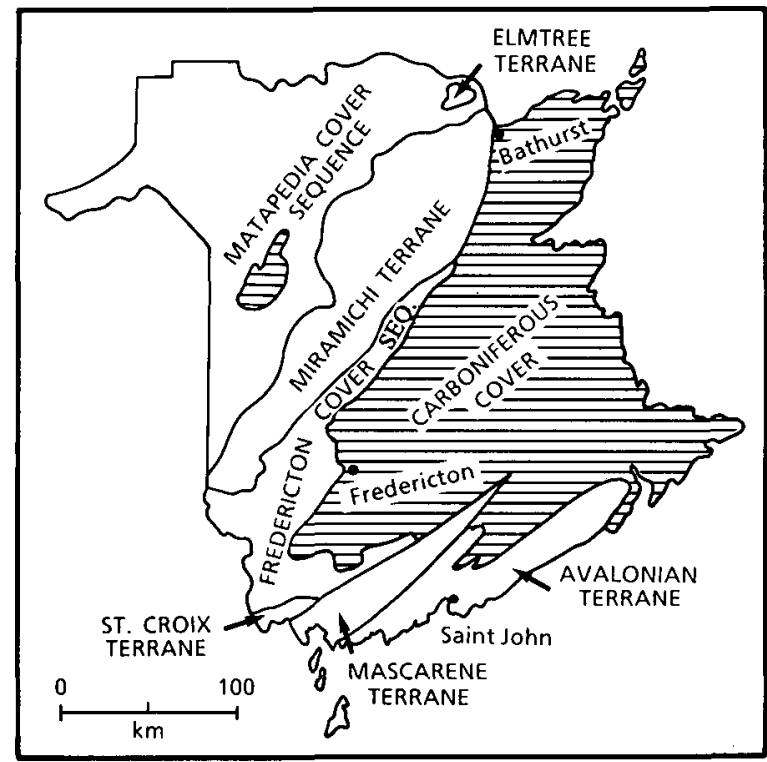

Fig. 1. Generalized map of tectonostratigraphic zones of New Brunswick (modified from Fyffe et al., 1983). 
area, although such information may indicate if their characteristics are the same as those in the Bathurst area and they thus might be considered to be a suitable environment for stratiform sulphide mineralization. The purpose of this paper is to present geochemical data for the Ordovician volcanic rocks of the Tetagouche Group from the southwestern part of the Miramichi Terrane in the Meductic-Woodstock area of southwestern New Brunswick and to discuss their petrogenetic and geodynamic significance.

\section{GEOLOGICAL SETTING}

The lower part of the Tetagouche Group in northeastern New Brunswick is composed of a sequence of alternating Cambrian to Lower Ordovician quartzites and semipelites considered to be quartzose turbidites (Skinner, 1974; Fyffe, 1982) deposited on a continental margin off the Avalon Platform (Ruitenberg et al., 1977). The sequence is locally conformably overlain by calcareous phyllites that contain Arenigian shallow water fauna (Fyffe, 1976; Nowlan, 1981; Fyffe et al., 1983; Neuman, 1984). The upper part of the Tetagouche Group is composed of felsic volcanic rocks and overlying mafic volcanic rocks intercalated with hematitic and manganiferous slates and cherts. The volcanic sequence is overlain by graywackes containing debris from the underlying volcanic rocks (Helmstaedt, 1971; Skinner, 1974). The fossiliferous strata indicate that the upper part of the group is of Middle Ordovician age (Kennedy et al., 1979; Nowlan, 1981).

The tectonic setting of the basalts of the Tetagouche Group has been a matter of controversy. In the Bathurst area, the basalts were interpreted by Rast and Stringer (1974) and Pajari et al. (1977) to have been formed in an ensialic island arc environment with a subduction zone dipping to the southeast. On the other hand, Whitehead and Goodfellow (1978) argued that two types of basaltic rocks are present: tholeiitic basalts that resemble ocean-floor basalts and alkali basalts comparable to those of oceanic islands. The recent study of van Staal (1987) has demonstrated that the Ordovician basaltic rocks include midocean ridge basalts and within-plate basalts that were both emplaced in a marginal-sea or back-arc basin environment.

The geology of the Tetagouche Group in the MeducticWoodstock area of southwestern New Brunswick has been described by Venugopal $(1978,1979)$. The Tetagouche Group extends for more than $10 \mathrm{~km}$ between two tectonostratigraphic zones, the Matapedia Cover Sequence on the west and the Fredericton Cover Sequence on the east (Figs. 1, 2). The stratigraphic column of the group is closely comparable to the type sections in the Bathurst area (Fyffe, 1976). The lower part of the Tetagouche succession in the Meductic area is represented by the quartzites and slates. They are overlain by black slates with graptolites of an early Ordovician age (middle- to lateArenigian; Fyffe et al., 1983). The volcanic sequence (Pocomoonshine volcanics of Venugopal, 1978, 1979), which is more than 3,000 m thick, conformably (Venugopal, 1979) overlies the black slates. The sequence is distinctly bimodal; subordinate felsic rocks are probably older than the mafic unit (Venugopal, 1979; Fyffe, 1982). The former are predominantly composed of volcanic tuffs containing beds of red ferromanganiferous slates and cherts (Poole, 1963; Venugopal, 1978, 1979) similar to the iron formation associated with massive stratiform sulphide deposits in the Bathurst area. Compared to the Bathurst area, the felsic volcanic rocks in the Woodstock-Meductic part of the Miramichi Terrane occur in rather limited amounts. Venugopal (1979) has estimated the thickness of the felsic unit to be in the range of about $600 \mathrm{~m}$. The overlying mafic volcanic rocks are represented by lava flows, tuffs and breccias. The rocks were affected by sub-greenschist regional metamorphism of prehnitepumpellyite grade (Venugopal, 1978, 1979). The volcanic sequence, in turn, underlies the sedimentary unit composed of intercalated slates, greywackes and limestones with graptolites and conodonts of early Caradocian age (Nowlan, 1981; Fyffe $e t$ al., 1983). In summary, volcanism in southwestern New Brunswick started in the Arenigian, reached its peak in the Llanvirnian to early Caradocian and ended by the middle-Caradocian (Fyffe et al., 1983). As detailed structural studies in the WoodstockMeductic area are lacking, it is unclear whether the basaltic suite is autochthonous or allochthonous like that in the Bathurst area (van Staal, 1987).

\section{PETROGRAPHIC NOTES AND CLINOPYROXENE COMPOSITION}

Relict primary minerals and igneous textures are commonly preserved in the volcanic rocks. The mafic lava flows are typically porphyritic with phenocrysts of clinopyroxene and plagioclase set in a fine-grained groundmass containing microlites of plagioclase and microphenocrysts of clinopyroxene and Fe-Ti oxides. Several samples have amygdules filled with chlorite and rarely carbonate. Plagioclase is generally albitized or saussuritized. Clinopyroxene is mostly fresh although in some samples it is altered mainly to chlorite and carbonate. Clinopyroxene phenocrysts commonly exhibit distinct zoning. Clinopyroxenes are predominantly low-Al and low-Ti augites, typical of basaltic rocks of orogenic zones (Table 1, Fig. 3). They display some variations in composition; $\mathrm{Ca}$ and $\mathrm{Al}$ decrease while $\mathrm{Si}, \mathrm{Fe}$ and $\mathrm{Mn}$ increase with decreasing $\mathrm{Mg} / \mathrm{Fe}$. Venugopal (1978, 1979) reported the occurrence of pumpellyite and prehnite in regional metamorphic assemblages of some of the mafic volcanic rocks.

The felsic volcanic rocks are mainly tuffs composed of plagioclase, K-feldspar and embayed quartz crystal fragments enclosed in matrix material containing chlorite, sericite, calcite and opaque.

\section{GEOCHEMISTRY}

\section{Sampling and Analytical Methods}

Due to poor exposure over a large part of the studied area, most samples of mafic rocks were collected from the vicinity of Oak Mountain, whereas the majority of felsic samples are from road-cuts along the Trans-Canada Highway (Fig. 2). Twentythree samples ( 19 basalts and basaltic andesites and 4 rhyolites) devoid of amygdules and secondary veins were selected for 


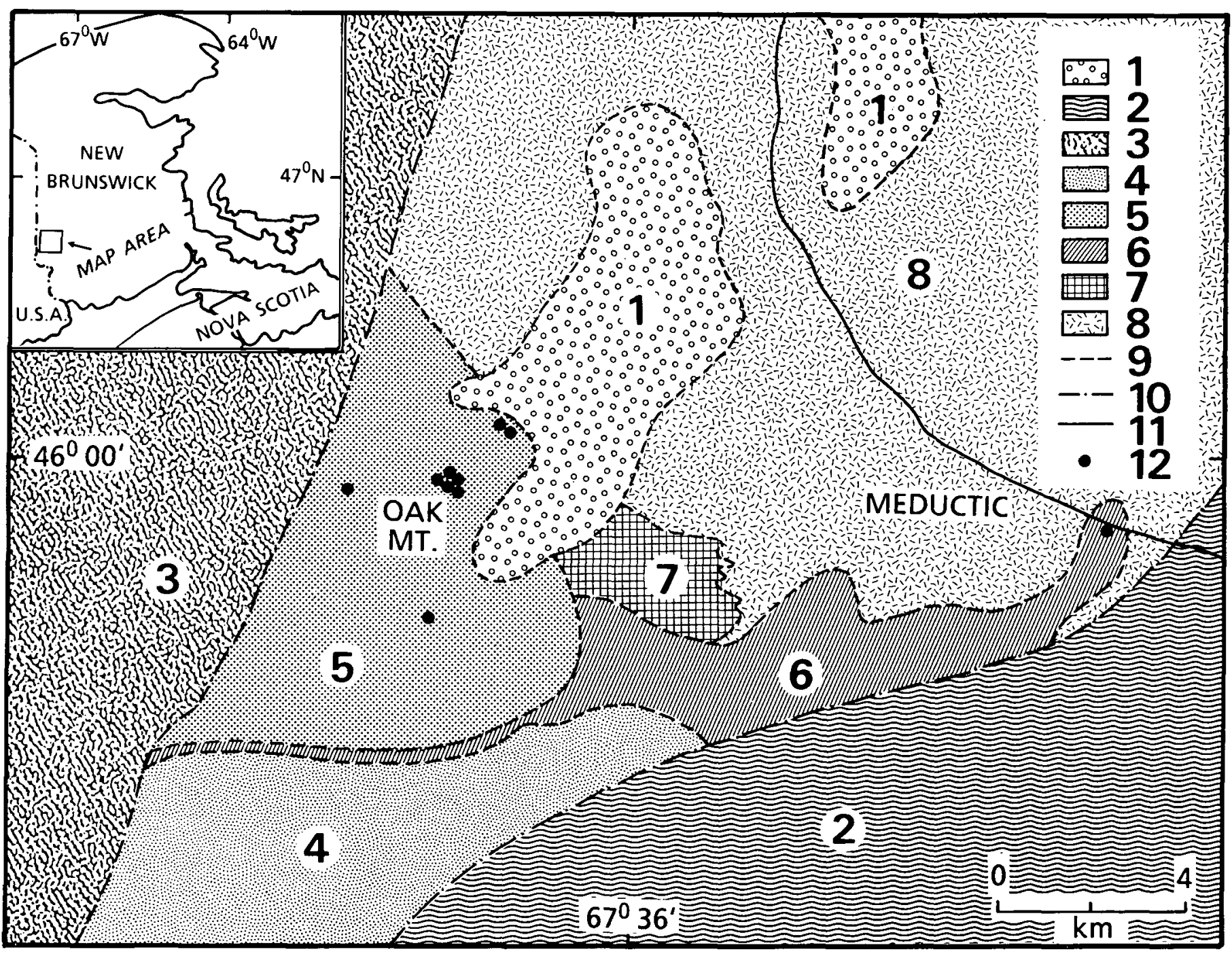

Fig. 2. Generalized geological map of the Meductic-Woodstock area (after Venugopal, 1978, 1979). Legend: (1) Devonian granite; (2) Silurian and Devonian sedimentary and minor granitic rocks; (3) Silurian sedimentary rocks; (4) Ordovician Belle Lake slate; (5) mafic members of Ordovician Pocomoonshine volcanic suite; (6) felsic members of Ordovician Pocomoonshine volcanic suite; (7) Ordovician black slate and minor sandstone; (8) Cambro-Ordovician quartzite; (9) geologic contact; (10) fault; (11) Trans-Canada Highway; (12) sample location for chemical analysis given in Table 2 .

analysis from a set of over 50 specimens. Major and some trace elements (Rb, $\mathrm{Sr}, \mathrm{Ba}, \mathrm{Ga}, \mathrm{Zr}, \mathrm{Y}, \mathrm{Nb}, \mathrm{Cr}, \mathrm{Ni}, \mathrm{V}, \mathrm{Zn}$ and $\mathrm{Cu})$ were analyzed by $\mathrm{X}$-ray fluorescence using fused discs (for the major elements) and pressed powder pellets (for the trace elements). Other trace elements (Sc, Hf, Ta, Co, Th, La, Ce, Nd, Sm, Eu, Tb, $\mathrm{Yb}$ and $\mathrm{Lu}$ ) were analyzed by instrumental neutron activation on thirteen samples. The precision and accuracy of the data are given by Dostal et al. (1986). Briefly, the precision of the trace element data is usually better than $10 \%$. The analyses of the samples are given in Table 2.

\section{Alteration}

Because the volcanic rocks have suffered low-grade metamorphism, the original chemical composition may have been modified. Several mafic rocks have high loss-on-ignition (LOI), up to $4.5 \%$. Some major elements in the mafic rocks, particularly $\mathrm{Na}$ and $\mathrm{K}$, are highly variable (Table 2). The significant scatter of the abundances of these elements as well as of Ca is probably due to alteration. Several trace elements, including $\mathrm{Rb}$ and $\mathrm{Ba}$ that display positive correlation with $\mathrm{K}$, seem to be also redistributed in some basalts. Thus to limit the effect of secondary processes, the discussion is based mainly on the less mobile elements such as high-field-strength elements (HFSE) and rare earth elements (REE), which are usually considered to be relatively immobile during secondary processes (e.g., Winchester and Floyd, 1977; Condie, 1982).

\section{Whole-Rock Geochemistry}

The volcanic rocks are distinctly bimodal. The mafic rocks have $\mathrm{SiO}_{2}$ contents (on LOI-free basis) ranging from 48 to $57 \%$ while the felsic members have $>70 \% \mathrm{SiO}_{2}$. The mafic rocks have major element compositions typical of volcanic arc lavas as is also shown by the $\mathrm{FeO}-\mathrm{MgO}-\mathrm{Al}_{2} \mathrm{O}_{3}$ diagram (Fig. 4; Pearce et al., 1977, 1988). They are high in $\mathrm{Al}_{2} \mathrm{O}_{3}$ and $\mathrm{CaO}$ but low in $\mathrm{TiO}_{2}$ and 
Table 1. Average composition of clinopyroxene from basalts of the Tetagouche Group from the Woodstock-Meductic area.

\begin{tabular}{cccccccccc}
\hline $\mathrm{SiO}_{2}$ & $\mathrm{Al}_{2} \mathrm{O}_{3}$ & $\mathrm{FeO}$ & $\mathrm{Mno}$ & $\mathrm{MgO}$ & $\mathrm{CaO}$ & $\mathrm{Na} 2 \mathrm{O}$ & $\mathrm{TiO}_{2}$ & $\mathrm{Cr}_{2} \mathrm{O}_{3}$ \\
\hline $\begin{array}{c}50.39 \\
(0.54)\end{array}$ & $\begin{array}{c}3.84 \\
(0.85)\end{array}$ & $\begin{array}{c}8.42 \\
(1.53)\end{array}$ & $\begin{array}{c}0.21 \\
(0.10)\end{array}$ & $\begin{array}{c}15.75 \\
(0.45)\end{array}$ & $\begin{array}{c}20.71 \\
(0.91)\end{array}$ & $\begin{array}{c}0.25 \\
(0.05)\end{array}$ & $\begin{array}{c}0.39 \\
(0.09)\end{array}$ & $\begin{array}{c}0.04 \\
(0.07)\end{array}$ \\
\hline
\end{tabular}

Number of Cations per 6 oxygens

\begin{tabular}{llllllllll}
\hline $\mathrm{Si}$ & $\mathrm{Al}$ & $\mathrm{Al}$ & $\mathrm{Cr}$ & $\mathrm{Ti}$ & $\mathrm{Mn}$ & $\mathrm{Fe}^{2+}$ & $\mathrm{Mg}$ & $\mathrm{Ca}$ & $\mathrm{Na}$ \\
\hline 1.856 & 0.144 & 0.022 & 0.001 & 0.011 & 0.007 & 0.259 & 0.865 & 0.817 & 0.018 \\
\hline
\end{tabular}

Analyses were done using an energy dispersive microprobe. The values were obtained from 15 analyses of 3 samples. Standard deviations are given in parentheses. $\mathrm{FeO}_{\mathrm{t}}$ is total $\mathrm{Fe}$ recalculated as $\mathrm{FeO}$.

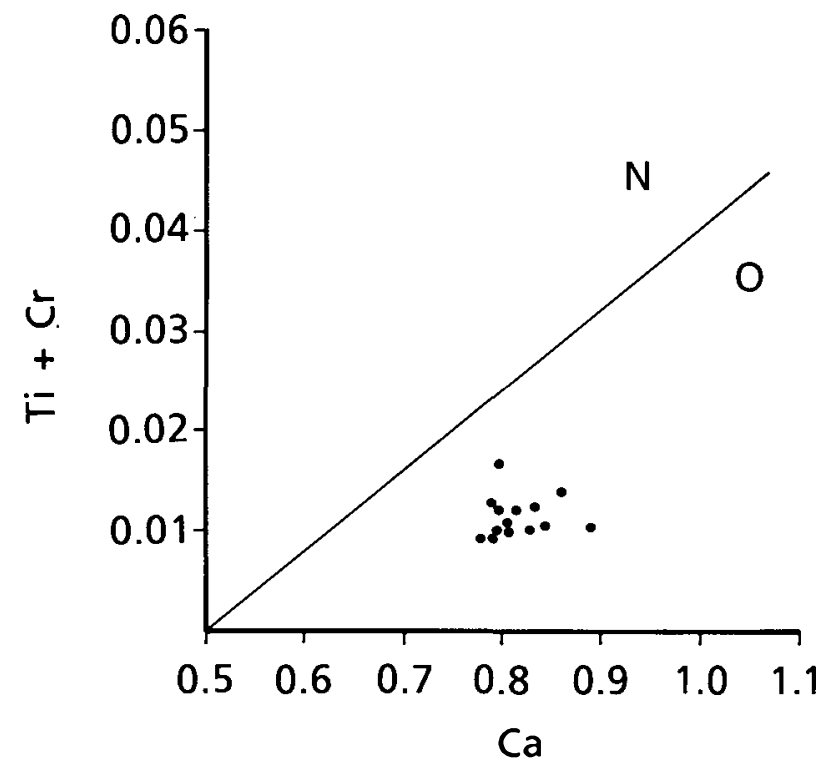

Fig. 3. $(\mathrm{Ti}+\mathrm{Cr}$ ) vs $\mathrm{Ca}$ (number of cations per 6 oxygens) diagram for clinopyroxenes of the basaltic rocks of the Tetagouche Group from the Woodstock-Meductic area. Dividing line between fields for clinopyroxene from orogenic $(\mathrm{O})$ and non-orogenic basalts $(\mathrm{N})$ after Leterrier et al. (1982).

$\mathrm{P}_{2} \mathrm{O}_{s}$ (Table 2), features which are characteristic of calc-alkalic rocks. Their calc-alkalic nature is also suggested by the relationships of $\mathrm{FeO}_{1}$ vs $\mathrm{FeO} / \mathrm{MgO}$ (Fig. 5; Miyashiro, 1974) and $\mathrm{TiO}_{2}-$ MnO- $\mathrm{P}_{2} \mathrm{O}_{5}$ (Fig. 6; Mullen, 1983). Although the majority of the basaltic rocks show limited compositional dispersion, some of them are distinctly fractionated and their $(\mathrm{Mg})(=$ mole $\% \mathrm{MgO} /$ $\mathrm{MgO}+\mathrm{FeO}_{\mathrm{t}}$ ) values range from 0.63 to 0.51 . The low concentrations of $\mathrm{Ni}(<35 \mathrm{ppm})$ and $\mathrm{Cr}(<160 \mathrm{ppm})$ are also indicative of extensive fractionation of mafic minerals. The decrease of $\mathrm{Ni}, \mathrm{Cr}$ and $\mathrm{Sc}$ with decreasing $(\mathrm{Mg})$ suggests the fractionation of mafic minerals--pyroxenes and possibly olivine. The abundances of $\mathrm{Ti}, \mathrm{Fe}$ and $\mathrm{V}$ remain nearly constant with $(\mathrm{Mg})$, suggesting a subordinate amount of crystallization of Fe-Ti oxides. The rocks also have low $\mathrm{Ti} / \mathrm{V}$ ratios (usually $<15$ ) but high $\mathrm{V} / \mathrm{Ni}$ and $\mathrm{V} / \mathrm{Cr}$, typical of volcanic arc rocks (Ewart, 1982; Shervais, 1982).

The incompatible elements, including $\mathrm{Zr}, \mathrm{Nb}, \mathrm{Y}$ and $\mathrm{P}$, show covariation amongst themselves and also with REE and exhibit negative correlations with compatible elements such as $\mathrm{Mg}, \mathrm{Ni}$ and $\mathrm{Cr}$ suggesting the relative immobility of all these elements during metamorphism. The interrelation of Ti-Zr-Y (Fig. 7; Pearce and Cann, 1973) is indicative of the calc-alkalic character of the basalts. The REE patterns of the basaltic rocks (Fig. 8) display distinct light REE (LREE) enrichment and relatively flat heavy REE (HREE) with $\mathrm{La} / \mathrm{Yb}$ ranging from 7 to 11. The rocks have rather similar patterns but varying total REE concentrations. The variations mainly reflect low-pressure fractionation of common rock-forming minerals--pyroxene, plagioclase and olivine--a process which leads essentially to the enrichment of total REE in the residual magma with relatively little change of the fractionation patterns. The small negative Eu anomaly in the sample with the highest REE abundances indicates fractionation of plagioclase. The REE patterns are typical of basaltic rocks from volcanic arc regimes (e.g., Gill, 1981; Dostal et al., 1982; Hickey et al., 1984).

The chemical characteristics of the basaltic rocks are summarized in Figure 9, where the composition of the representative samples is normalized to mid-ocean ridge basalts (MORB) (Pearce, 1982). Compared to MORB, the basalts are enriched in large-ion-lithophile-elements (LILE) including $\mathrm{Sr}, \mathrm{K}, \mathrm{Ba}$, Th and LREE relative to HFSE including $\mathrm{Nb}, \mathrm{Ta}, \mathrm{Zr}, \mathrm{Hf}$ and $\mathrm{Ti}$. The concentration of elements less incompatible than $\mathrm{Zr}$ is usually below those of MORB. The shape of the pattern is characterized by the depletion of $\mathrm{Nb}$ and $\mathrm{Ta}$ in relation to $\mathrm{Th}$ and $\mathrm{Ce}$, negative anomalies of $\mathrm{Zr}, \mathrm{Hf}$ and $\mathrm{Ti}$ and a sloping of the segment from $\mathrm{Ce}$ 
Table 2. Representative chemical analyses of volcanic rocks from the Woodstock-Meductic area.

\begin{tabular}{|c|c|c|c|c|c|c|c|c|c|c|c|c|c|c|c|c|c|c|c|c|c|c|c|}
\hline & 127 & 128 & 130 & 138 & 141 & 142 & 154 & 157 & 166 & 126 & 129 & 131 & 132 & 146 & 156 & 167 & 168 & 169 & 173 & 102 & 103 & 152 & 124 \\
\hline $\mathrm{SiO}_{2}(\%)$ & 50.11 & 50.52 & 51.58 & 47.35 & 49.32 & 50.35 & 48.73 & 51.49 & 52.98 & 50.41 & 47.09 & 49.45 & 48.62 & 55.54 & 53.07 & 53 & 46.12 & 54.92 & 52.76 & 74.62 & 77.43 & 70.98 & 77.82 \\
\hline $\mathrm{TiO}_{2}$ & 0.52 & 0.44 & 0.50 & 0.56 & 0.74 & 0.45 & 0.56 & 0.79 & 0.56 & 0.46 & 0.46 & 0.50 & 0.52 & 0.39 & 0.49 & 0.53 & 0.59 & 0.50 & 0.53 & 0.12 & 0.10 & 0.14 & 0.11 \\
\hline $\mathrm{Al}_{2} \mathrm{O}_{3}$ & 17.76 & 16.44 & 17.89 & 17.44 & 18.33 & 18.39 & 16.62 & 15.52 & 18.66 & 17.19 & 17.65 & 18.46 & 19.06 & 15.84 & 17.76 & 17.61 & 19 & 17.21 & 17.26 & 13.64 & 12.33 & 15.49 & 11.99 \\
\hline $\mathrm{Fe}_{2} \mathrm{O}_{3}$ & 9.32 & 8.21 & 8.50 & 9.30 & 8.62 & 7.76 & 8.93 & 10.03 & 8.61 & 7.81 & 9.10 & 8.59 & 9.05 & 8.03 & 8.03 & 9.19 & 11.06 & 7.62 & 8.11 & 2.14 & 1.63 & 3.15 & 1.68 \\
\hline $\mathrm{MnO}$ & 0.17 & 0.15 & 0.15 & 0.19 & 0.15 & 0.14 & 0.17 & 0.17 & 0.14 & 0.12 & 0.18 & 0.15 & 0.16 & 0.14 & 0.11 & 0.16 & 0.18 & 0.14 & 0.17 & 0.29 & 0.24 & 0.27 & 0.27 \\
\hline $\mathrm{MgO}$ & 6.38 & 6.99 & 5.88 & 6.37 & 4.76 & 5.98 & 6.76 & 6.06 & 4.61 & 5.67 & 7.73 & 4.56 & 5.43 & 4.83 & 4.21 & 4.76 & 6.80 & 4.49 & 4.82 & 2.19 & 1.67 & 3.04 & 1.74 \\
\hline $\mathrm{CaO}$ & 6.54 & 10.44 & 8.59 & 12.57 & 9.64 & 9.14 & 10.58 & 8.53 & 5.42 & 11.39 & 10.93 & 10.77 & 8.83 & 7.67 & 10.08 & 6.30 & 8.77 & 7.26 & 9.63 & 0.14 & 0.16 & 0.02 & 0.16 \\
\hline $\mathrm{Na}_{2} \mathrm{O}$ & 4.33 & 2.39 & 2.13 & 1.99 & 4.06 & 1.97 & 3.13 & 1.89 & 5.42 & 2.33 & 2.50 & 2.71 & 2.69 & 4.16 & 2.21 & 3.39 & 1.96 & 2.93 & 2.88 & 3.46 & 4.91 & 1.62 & 4.15 \\
\hline $\mathrm{K}_{2} \mathrm{O}$ & 1.18 & 1.17 & 1.87 & 0.24 & 0.92 & 3.01 & 0.76 & 1.92 & 0.75 & 0.44 & 0.70 & 1.32 & 2.22 & 0.65 & 1.12 & 1.54 & 1.48 & 1.53 & 0.92 & 1.89 & 0.88 & 3.30 & 1.18 \\
\hline $\mathrm{P}_{2} \mathrm{O}_{5}$ & 0.14 & 0.12 & 0.12 & 0.15 & 0.21 & 0.14 & 0.15 & 0.23 & 0.17 & 0.15 & 0.12 & 0.14 & 0.14 & 0.11 & 0.16 & 0.15 & 0.16 & 0.14 & 0.13 & 0.05 & 0.04 & 0.05 & 0.04 \\
\hline LOI & 3.00 & 3.30 & 3.80 & 4.50 & 3.00 & 3.00 & 3.90 & 2.80 & 2.40 & 4.50 & 4.20 & 3.80 & 3.80 & 3.00 & 3.30 & 3.10 & 4.30 & 3.70 & 3.00 & 1.80 & 1.30 & 2.80 & 1.50 \\
\hline Total & 99.45 & 100.17 & 100.61 & 100.66 & 99.75 & 100.33 & 100.29 & 99.43 & 99.72 & 100.47 & 100.66 & 100.45 & 100.52 & 100.36 & 100.54 & 99.73 & 100.42 & 100.44 & 100.21 & 100.34 & 100.69 & 100.86 & 100.64 \\
\hline $\mathrm{Rb}(\mathrm{ppm})$ & 37 & 30 & 61 & 5 & 16 & 84 & 20 & 34 & 19 & 11 & 15 & 33 & 57 & 15 & 34 & 46 & 39 & 41 & 23 & 58 & 25 & 98 & 33 \\
\hline $\mathrm{Sr}$ & 512 & 369 & 323 & 221 & 403 & 317 & 287 & 631 & 268 & 131 & 409 & 642 & 466 & 174 & 812 & 326 & 625 & 511 & 276 & 117 & 159 & 44 & 137 \\
\hline $\mathrm{Ba}$ & 165 & 216 & 301 & 14 & 254 & 707 & 95 & 603 & 199 & 81 & 117 & 265 & 542 & 179 & 122 & 244 & 297 & 280 & 167 & 664 & 248 & 1118 & 366 \\
\hline Sc & 33.5 & 35.9 & 32.3 & 37.6 & 31.8 & 28.9 & 37.0 & 33.6 & 27.5 & & & & & & & & & & & 9.44 & 6.80 & 11.00 & 8.05 \\
\hline V & 274 & 231 & 243 & 300 & 313 & 227 & 283 & 291 & 267 & 234 & 252 & 263 & 261 & 269 & 216 & 244 & 283 & 241 & 276 & 8 & 5 & 10 & 5 \\
\hline $\mathrm{Cr}$ & 91 & 159 & 50 & 114 & 24 & 50 & 118 & 178 & 26 & 103 & 137 & 57 & 59 & 133 & 21 & 21 & 43 & 39 & 52 & 4 & 2 & 4 & 4 \\
\hline $\mathrm{Ni}$ & 15 & 20 & 17 & 14 & 10 & 22 & 18 & 30 & 9 & 15 & 33 & 9 & 15 & 16 & 10 & 10 & 10 & 9 & 12 & 13 & 14 & 30 & 21 \\
\hline Co & 40.9 & 46.6 & 44.1 & 51.5 & 45.8 & 47.1 & 44.4 & 50.6 & 35.1 & & & & & & & & & & & & & & \\
\hline $\mathrm{Cu}$ & 65 & 68 & 35 & 73 & 117 & 51 & 61 & 134 & 44 & 59 & 71 & 57 & 58 & 48 & 52 & 43 & 61 & 33 & 52 & 1 & & & 11 \\
\hline $\mathrm{Zn}$ & 76 & 73 & 70 & 82 & 86 & 68 & 72 & 98 & 81 & 67 & 74 & 70 & 73 & 66 & 75 & 92 & 93 & 61 & 74 & 63 & 49 & 85 & 57 \\
\hline $\bar{Y}$ & 13 & 12 & 14 & 14 & 18 & 13 & 12 & 20 & 15 & 13 & 12 & 14 & 14 & 18 & 13 & 15 & 15 & 13 & 14 & 30 & 39 & 56 & 46 \\
\hline $\mathrm{Zr}$ & 69 & 55 & 57 & 60 & 80 & 55 & 59 & 99 & 74 & 57 & 54 & 64 & 64 & 65 & 80 & 73 & 75 & 65 & 63 & 139 & 110 & 139 & 125 \\
\hline $\mathrm{Nb}$ & 7 & 3 & 4 & 6 & 6 & 5 & 6 & 9 & 4 & 5 & 5 & 5 & 7 & 6 & 7 & 6 & 5 & 6 & 6 & 13 & 11 & 11 & 12 \\
\hline $\mathrm{Hf}$ & 1.39 & 1.11 & 1.15 & 1.28 & 1.83 & 1.09 & 1.28 & 2.05 & 1.55 & & & & & & & & & & & 4.72 & 3.41 & 4.54 & 2.09 \\
\hline $\mathrm{Ta}$ & 0.31 & 0.20 & 0.24 & 0.30 & 0.36 & 0.29 & 0.34 & 0.52 & 0.38 & & & & & & & & & & & 1.21 & 1.26 & 1.10 & 1.20 \\
\hline $\mathrm{Ga}$ & 18 & 17 & 21 & 23 & 19 & 15 & 23 & 21 & 22 & 24 & 25 & 19 & 25 & 24 & 22 & 21 & 22 & 18 & 20 & 19 & 18 & 24 & 14 \\
\hline Th & 3.55 & 2.57 & 2.56 & 3.52 & 4.08 & 3.81 & 3.60 & 4.63 & 3.65 & & & & & & & & & & & 9.30 & 6.46 & 9.01 & 7.06 \\
\hline $\mathrm{La}$ & 10.3 & 7.70 & 8.00 & 11.3 & 13.7 & 11.6 & 11.1 & 16.7 & 11.9 & & & & & & & & & & & 53.0 & 25.2 & 39.7 & 33.3 \\
\hline $\mathrm{Ce}$ & 22.9 & 17.9 & 17.7 & 25.6 & 31.2 & 25.0 & 25.1 & 36.7 & 24.8 & & & & & & & & & & & 88.4 & 57.7 & 92.4 & 57.5 \\
\hline $\mathrm{Nd}$ & 11.6 & 8.71 & & 12.3 & 15.8 & 11.5 & 12.3 & 19.0 & 11.5 & & & & & & & & & & & & 27.0 & 42.2 & \\
\hline Sm & 2.50 & 1.98 & 2.10 & 2.76 & 3.58 & 2.50 & 2.69 & 3.98 & 2.65 & & & & & & & & & & & 8.69 & 6.04 & 9.21 & 5.97 \\
\hline $\mathrm{Eu}$ & 0.70 & 0.55 & 0.64 & 0.81 & 1.02 & 0.65 & 0.74 & 0.99 & 0.73 & & & & & & & & & & & 0.74 & 0.58 & 0.85 & 0.58 \\
\hline $\mathrm{Tb}$ & 0.35 & 0.32 & 0.34 & 0.36 & 0.49 & 0.34 & 0.39 & 0.53 & 0.39 & & & & & & & & & & & 1.04 & 1.27 & 1.79 & 1.27 \\
\hline Yb & 1.27 & 1.11 & 1.16 & 1.30 & 1.76 & 1.09 & 1.42 & 1.91 & 1.42 & & & & & & & & & & & 3.95 & 4.94 & 6.74 & 5.38 \\
\hline Lu & 0.21 & 0.19 & 0.20 & 0.22 & 0.28 & 0.19 & 0.23 & 0.31 & 0.24 & & & & & & & & & & & 0.61 & 0.78 & 1.02 & 0.8 \\
\hline
\end{tabular}




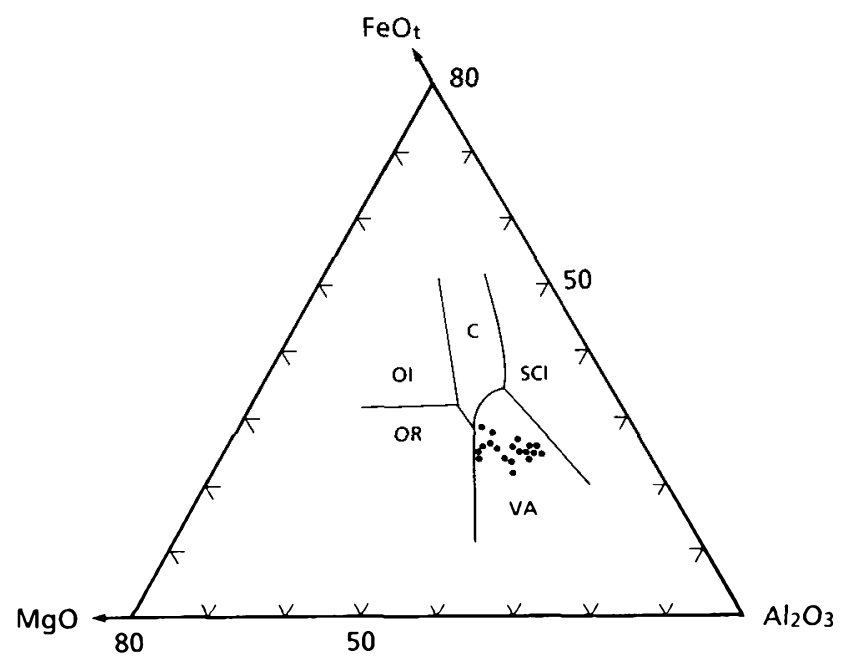

Fig. 4. $\mathrm{FeO},-\mathrm{MgO}-\mathrm{Al}_{2} \mathrm{O}_{3}$ discrimination diagram of Pearce et al. (1977, 1988) for the mafic rocks of the Tetagouche Group from the WoodstockMcductic area. OI - ocean-island basalts; OR - ocean-ridge and oceanfloor basalts; VA - volcanic arc basalts; SCI - spreading-centre island basalts; $\mathrm{C}$ - continental basalts.

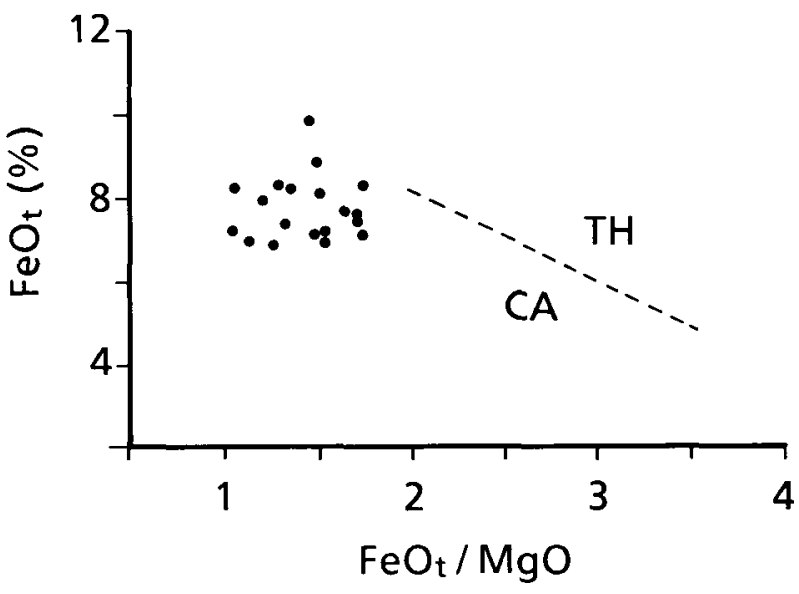

Fig. 5. $\mathrm{FeO}_{1}$ vs $\mathrm{FeO} / \mathrm{MgO}$ diagram for manic rocks of the Tetagouche Group from the Woodstock-Meductic area. Dividing line between tholeiitic (TH) and calc-alkalic (CA) fields after Miyashiro (1974).

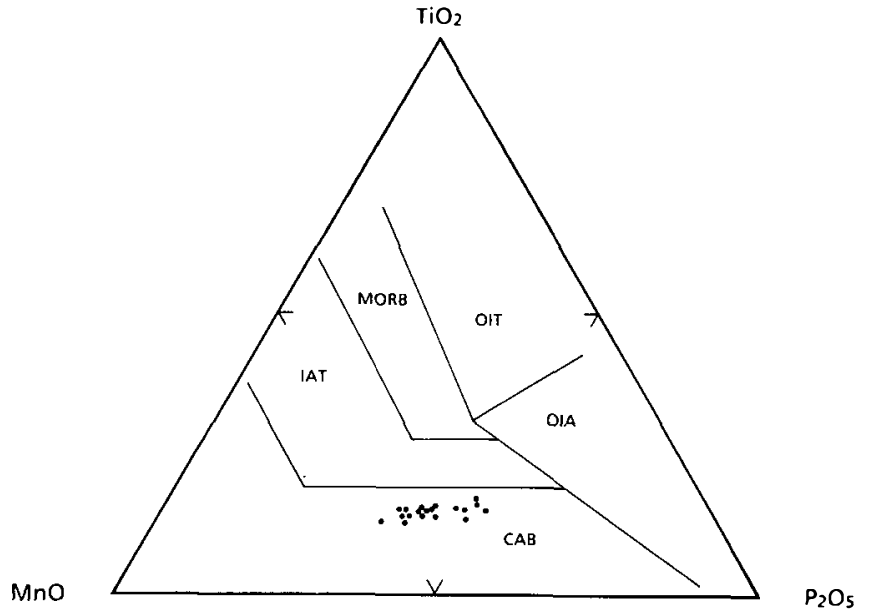

Fig. 6. $\mathrm{TiO}_{2}-\mathrm{MnO}(\mathrm{X} 10)-\mathrm{P}_{2} \mathrm{O}_{5}(\mathrm{X} 10)$ discrimination diagram of Mullen (1983) for the mafic rocks of the Tetagouche Group from the Woodstock-Meductic area. Fields: OIT - ocean-island tholeiites; OIA - oceanisland alkali basalts; MORB - mid-ocean ridge basalts; IAT - island arc tholciites; $\mathrm{CAB}$ - calc-alkalic basalts.

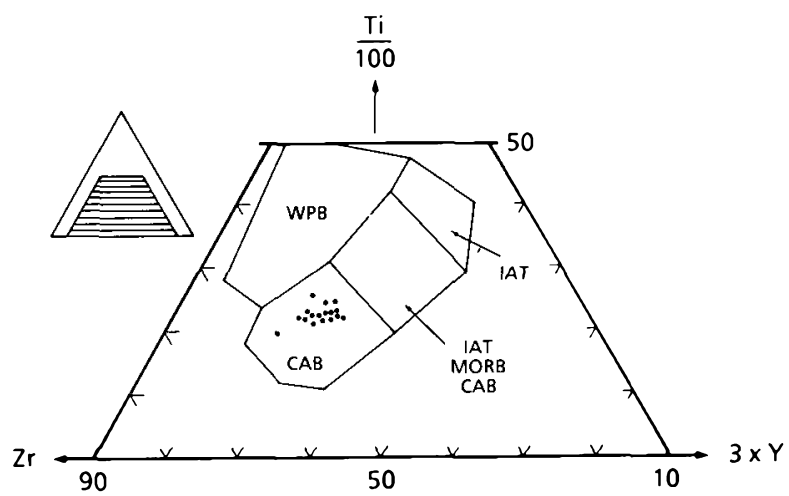

Fig. 7. Ti-Zr-Y discrimination diagram of Pearce and Cann (1973) for the basaltic rocks $\left(\mathrm{SiO}_{2}<56 \%\right)$ of the Tetagouche Group from the Woodstock-Meductic area. Fields: WPB - within-plate basalts; IAT island-arc tholeiites; MORB - ocean-floor basalts; CAB - calc-alkalic basalts.

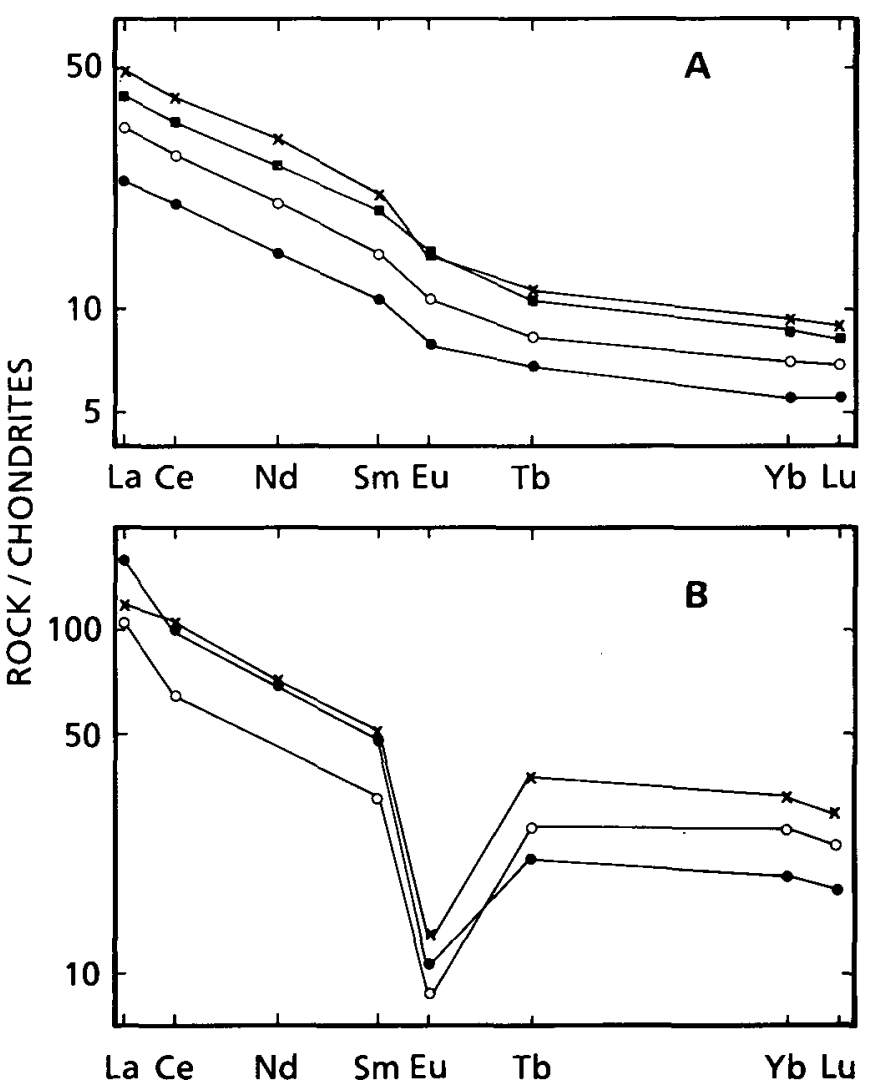

Fig. 8. Chondrite-normalized REE abundances in the Tetagouche Group of the Woodstock-Meductic area. (A) Basaltic rocks, - sample 128; - 141;O-154; X-157. (B) Rhyolitic rocks, O- sample 102; O$124 ; X-152$.

to Yb, typical of calc-alkalic basalts (Pearce, 1982, 1983). The enrichment of $\mathrm{K}, \mathrm{Rb}, \mathrm{Sr}$ and $\mathrm{Ba}$ as well as Th relative to $\mathrm{Ta}$ and $\mathrm{Nb}$ are those generally observed in calc-alkalic rocks.

The felsic rocks are rhyolites with $>70 \% \mathrm{SiO}_{2}$ and low contents of $\mathrm{Al}_{2} \mathrm{O}_{3}$ and $\mathrm{K}_{2} \mathrm{O}$ (usually <2\%). Compared to similar rocks from the Bathurst area (Whitehead and Goodfellow, 1978), they are lower in $\mathrm{Ti}, \mathrm{P}$ and $\mathrm{Zr}$. There are also differences in the abundances of the mobile elements. The Bathurst rocks have higher contents of $\mathrm{K}$ and $\mathrm{Rb}$ but lower $\mathrm{Na}$ than most felsic rocks 


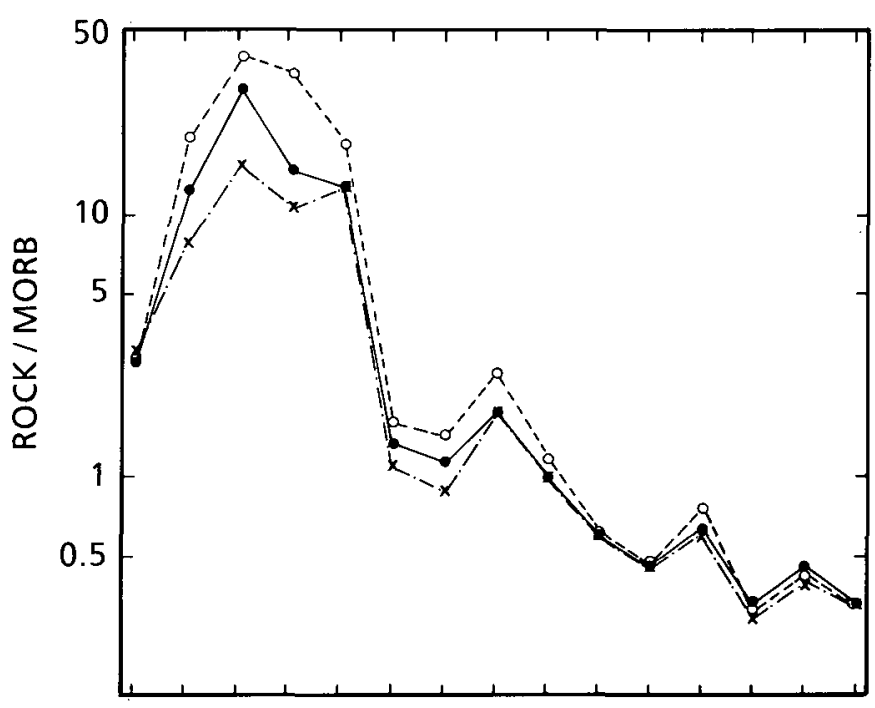

Sr K RbBa Th Ta NbCe P Zr Hf Sm Ti Y Yb

Fig. 9. MORB-normalized incompatible element patterns (Pearce, 1982,1983 ) of the basaltic rocks of the Tetagouche Group from the Woodstock-Meductic area. X-sample 128;0-130;O- 142.

from the Woodstock-Meductic area. Although $\mathrm{K}$ is variable in the felsic rocks, the $\mathrm{K} / \mathrm{Rb}$ and $\mathrm{K} / \mathrm{Ba}$ ratios remain relatively constant ( 285 and $\sim 25$, respectively). The positive correlation of these elements might be due to secondary processes. The REE of the felsic rocks display patterns that are found in some highsilica rhyolites and high-level silicic plutons (e.g., Ewart, 1979; Izett, 1981; Cullers et al., 1981). Chondrite-normalized patterns (Fig. 8) show only moderate light REE enrichment and a flat segment of heavy REE with $\mathrm{La} / \mathrm{Sm}$ between 4 and 6 and $\mathrm{La} / \mathrm{Yb}$ in the range of 5 to 14. The rocks have high abundances of HREE with $\mathrm{Yb}_{\mathrm{n}}(\mathrm{n}=$ chondrite-normalized) $\sim 20-35$. Large negative Eu anomalies and low concentrations of $\mathrm{Sr}$ are consistent with significant feldspar fractionation.

\section{PETROGENESIS}

\section{Basaltic Rocks}

The basaltic rocks have undergone extensive fractional crystallization involving the separation of pyroxene, plagioclase, olivine and Fe-Ti oxides. In fact, most compositional differences among the mafic rocks can be accounted for by this process.

Like other mafic calc-alkalic volcanic rocks of the orogenic zones, the basaltic rocks of the Woodstock-Meductic area were probably derived from an upper mantle source overlying the subduction zone. Some further information on the composition of the source can be obtained from interelement ratios such as Hf/ $\mathrm{Yb}-\mathrm{Th} / \mathrm{Yb}$ (Okamura, 1987) plotted in Figure 10. The field of "non-arc" basalts in Figure 10 outlines the range observed for the heterogeneous source compositions of MORB and within-plate basalts. Mantle processes which are not related to subduction as well as partial melting and fractional crystallization produce vectors with a slope of unity, parallel to this mantle field because

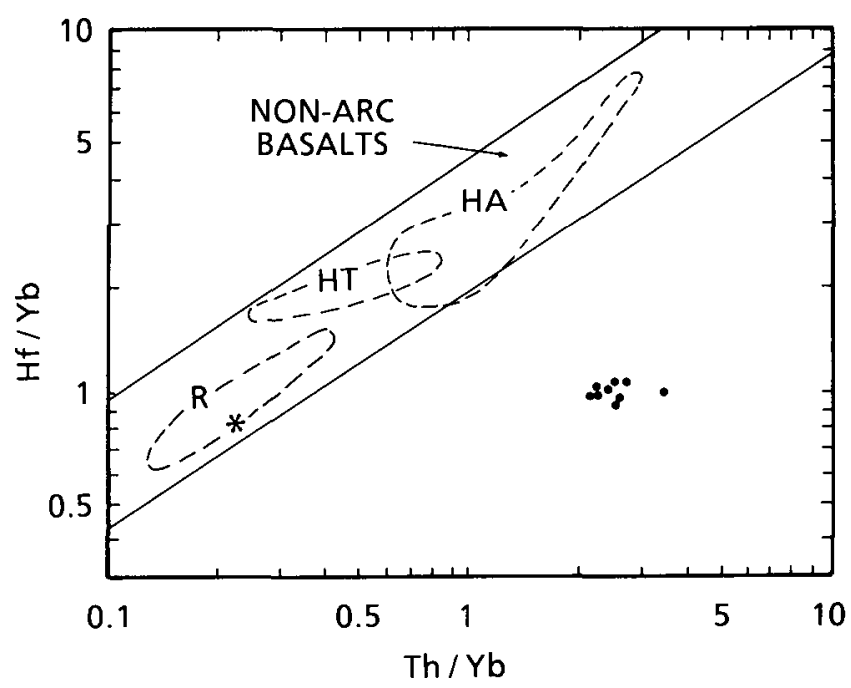

Fig. 10. Hf/Yb vs Th/Yb diagram (after Okamura, 1987) for the basaltic rocks of the Tetagouche Group from the Woodstock-Meductic area. Two parallel lines outline the 'mantle' array of the basalts from non-arc settings (Pearce, 1983; Okamura, 1987). The dashed lines show the fields of the Hawaiian alkali basalts (HA), Hawaiian tholeiites (HT) and Reykjanes Ridge basalts $(R)$ whereas the star represents primordial mantle (Okamura, 1987).

they enhance $\mathrm{Hf}$ and Th equally (Pearce 1983; Okamura, 1987). On the other hand, as the experiments of Tatsumi et al. (1986) confirmed, the subduction-related processes preferentially affect LILE including Th relative to HFSE (Pearce, 1983; Okamura, 1987) thus producing subhorizontal vectors on Figure 10. The basalts plot away from the non-orogenic basalt field, indicating the presence of a subduction-related component in their mantle source which originally had a composition, at least as far as the $\mathrm{Hf} / \mathrm{Yb}$ ratio is concerned, comparable to the primordial mantle (Fig. 10). However, the subhorizontal trends can also reflect crustal contamination as the crustal rocks also plot in the $\mathrm{Th} / \mathrm{Yb}$ enriched field (Pearce, 1982, 1983). There are indications that both subduction-related enrichment and crustal contamination played a role during the genesis of these basalts. The negative Ta$\mathrm{Nb}$ anomalies on the MORB-normalized trace element patterns accompanied by high Sr/Ce (Pearce, 1982) observed in the basalts are characteristic of a subduction zone component in the source. On the other hand the $\mathrm{Th} / \mathrm{La}$ ratio, which is considered to be a good indicator of crustal contamination (Hildreth and Moorbath, 1988), is high in the basalts $(\sim 0.30)$ relative to the mantle values $(\sim 0.12$; Sun, 1982) suggesting that the rocks were affected by crustal contamination.

The high $\mathrm{Zr} / \mathrm{Y}(>3)$ of the Woodstock basalts suggests that they were emplaced on the continental crust (Pearce, 1982), a conclusion consistent with the occurrence of abundant rhyolitic rocks in the Tetagouche Group. However, the relatively low HFSE abundances imply that the continental crust was thin. Likewise, the moderate $\mathrm{La} / \mathrm{Yb}$ and $\mathrm{Th} / \mathrm{Yb}$ ratios which overlap those from evolved island arcs and continental margins (Fig. 11) differ from the low values characteristic of primitive arcs or the high ratios typical of Andean arcs. 


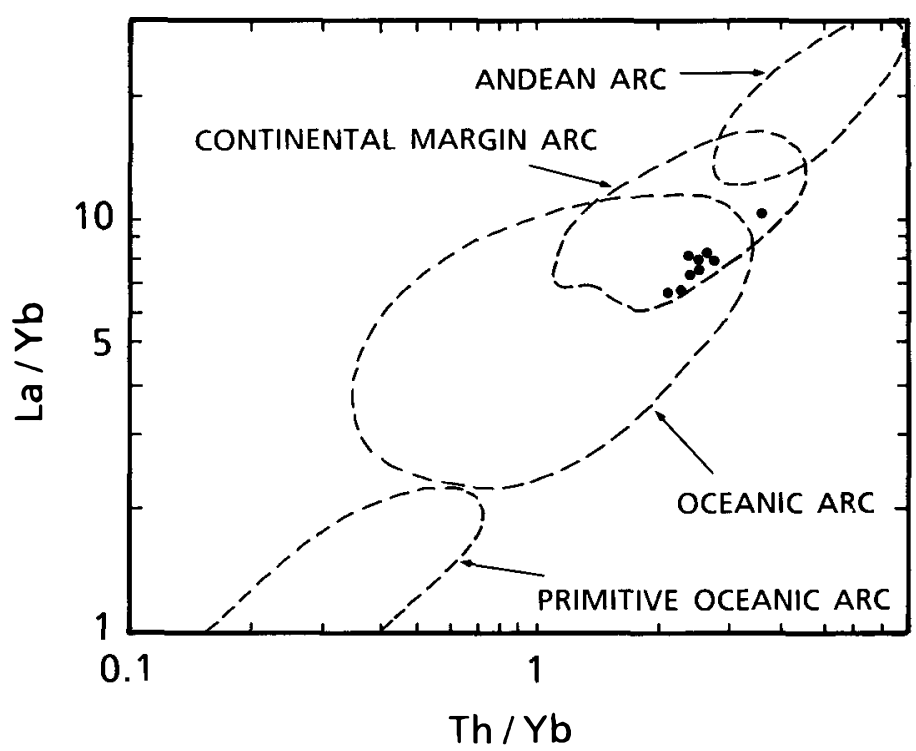

Fig. 11. La/Yb vs Th/Yb diagram for the mafic rocks of the Tetagouche Group from the Woodstock-Meductic area. Fields for modern arcrelated mafic lavas (after Crow and Condie, 1987).

\section{Felsic Rocks}

Two hypotheses which may be invoked for the origin of the felsic rocks are fractional crystallization of mafic magma and partial melting of the crust. There are several arguments against the derivation of the felsic rocks from the basalts by simple fractional crystallization. They include the lack of intermediate rocks and significant differences between the felsic and basaltic rocks in the ratios of incompatible elements that are not modified by fractional crystallization.

An alternative to the crystal fractionation model is generation of the felsic suite by partial melting. The anatectic model can account for the silicic composition of the rocks without necessitating large amounts of intermediate magmas. Petrological experiments exclude a direct partial melting of upper mantle ultramafic rocks (Wyllie et al., 1976) as a viable mechanism for the generation of silicic liquids. The trace element abundances of the felsic volcanics are similar to those of many granitic and rhyolitic rocks which are considered to be generated by partial melting of lower crust with intermediate composition (e.g., Crecraft et al., 1981; Cullers et al., 1981). The mineral assemblages of such a source probably include garnet and/or amphibole and could occur in either the granulite or amphibolite facies. The model calculations for REE during the melting of garnet granulite and amphibolite-facies crust are given in Figure 12 together with the parameters used. Low-silica I-type granites are formed by about $25 \%$ melting of the intermediate lower crust (Compston and Chappell, 1979; Stern and Gottfried, 1986); a smaller degree of melting would be required for the more silicic liquids. Melts formed by crustal melting are predominantly composed of feldspars and quartz (Wyllie, 1977). Since the analyzed felsic rocks contained more than $90 \%$ of normative felsic constituents, the trace element modelling assumed melting only of feldspars and quartz. The results of the calculation show that the liquids derived from garnet granulite by $25 \%$ or lesser degree of melting have much more fractionated REE patterns than the analyzed

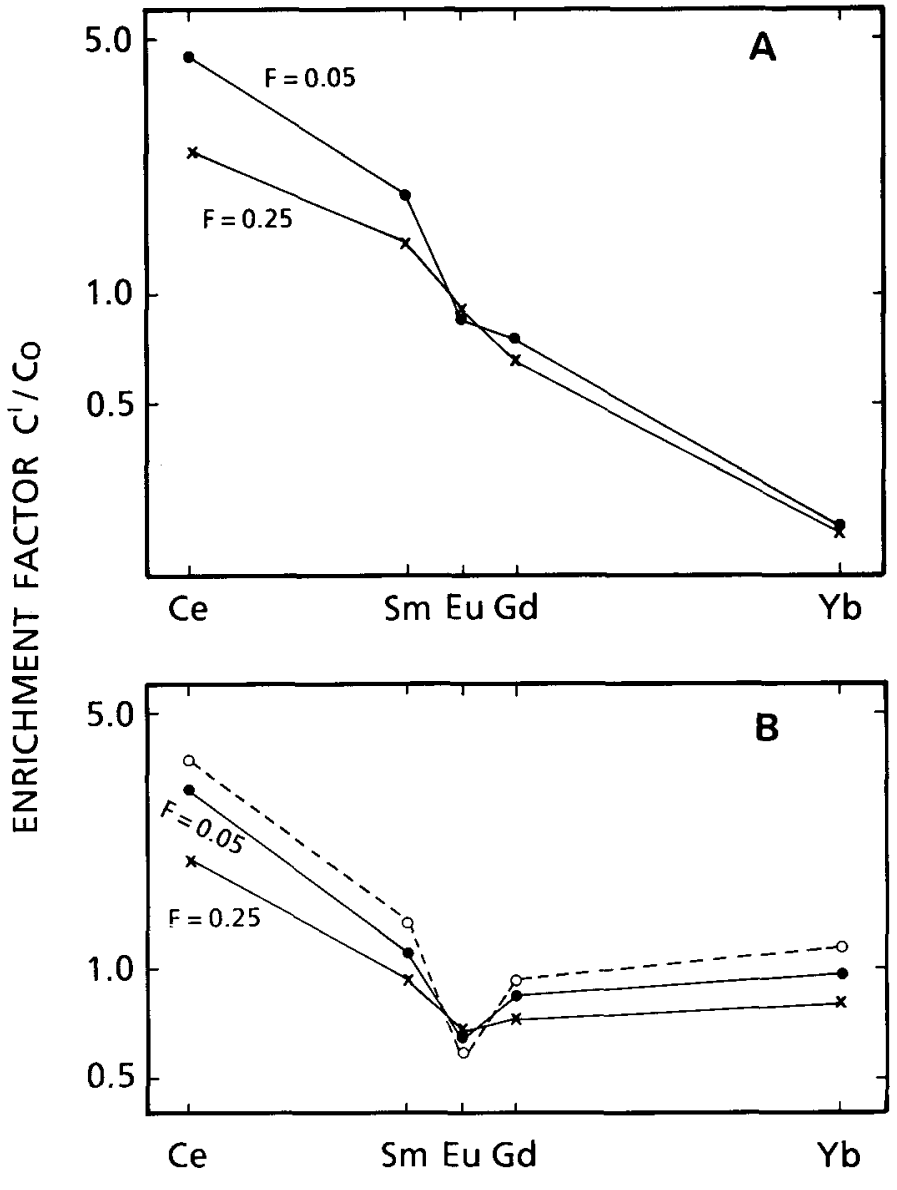

Fig. 12. Enrichment factors $\mathrm{C}^{1} / \mathrm{Co}$ (concentration in melt/concentration in rock source) for $R E E$ in melts produced by partial melting of granulite - (A) and amphibolite-facies (B) crustal rocks. Non-modal batch melting equation and partition coefficients of Arth (1976) and Henderson (1984) were used. F - fractions of melt produced. Mineral proportions of the source $(\mathrm{X})$ as well as melting proportions $(\mathrm{P})$ are after Stern and Gottfried (1986). (A) Gamet granulite: Phases (and their values for $X$ and $P$ ): $K$-feldspar 0.1 and 0.35 ; plagioclase 0.35 and 0.4; quartz 0.35 and 0.25 ; gamet 0.1 and 0.0 ; clinopyroxene 0.1 and 0.0 . (B) Amphibolite-facies source: $\mathrm{K}$-feldspar 0.1 and 0.35 ; plagioclase 0.35 and 0.4 ; quartz 0.35 and 0.25 and amphibole 0.2 and 0.0 . Dashed line in B - calculated REE abundances in the liquid produced by fractional crystallization of $20 \%$ feldspars (K-feldspar 0.5 and plagioclase 0.5 ) from the partial melt with $F=0.05$. The partition coefficients used are the same as for the melting model.

felsic rocks. The presence of zircon in the residue (Watson and Harrison, 1983) would generate an even steeper slope of the REE pattern. Thus, it appears that the felsic rocks cannot be readily produced by anatexis of garnet granulites. Calculated enrichment of the REE patterns of liquids formed by the melting of amphibolite-facies rocks are similar to those of the felsic rocks. Subsequent fractional crystallization of a feldspar-dominated assemblage would increase the REE content of the magma and increase the size of the negative Eu anomaly (Fig. 12). Considering the uncertainties inherent in these calculations, the results are consistent with the derivation of the felsic rocks by partial melting of amphibolite-facies sources. The REE data show that the source had a pattern with only slight LREE enrichment and 
relatively high abundances of HREE with a $\mathrm{La} / \mathrm{Yb}$ ratio significantly smaller than that given by Taylor and McLennan (1985) for the average crust.

The close spatial and temporal association of compositionally distinct magmas, characteristic of bimodal suites, suggests separate but related sources for the two magma types. A currently favored model (e.g., Bacon et al., 1980; Crecraft et al., 1981) assumes that the intrusion of mantle-derived basalts into the lower crust provides additional heat and leads to the anatexis of more silicic crustal rocks. Such a model is applicable to the studied volcanic sequence.

\section{TECTONIC IMPLICATIONS}

The basaltic rocks of the Tetagouche Group from the Woodstock area have compositions typical of rocks which were erupted in an ensialic orogenic environment (arc or back-arc setting). The basalts differ from those of the Tetagouche Group from the Bathurst area which include within-plate basalts and MORB (van Staal, 1987). The Ordovician sequences from the Woodstock and Bathurst areas, however, have rather similar stratigraphy and lithology, including comparable ages and the presence of an iron formation and graptolite-bearing shale (Fyffe, 1982) suggesting that they both may be part of a single Ordovician arc-back-arc system.

The occurrences of these volcanic sequences in the Tetagouche Group are consistent with a general tectonic model for the northern Appalachians (e.g., Strong, 1977; Hatch, 1982; van Staal, 1987; van der Pluijm and van Staal, 1988). The model envisages the presence of an Ordovician volcanic arc with an eastward-dipping subduction zone and a back-arc basin located east of the arc. Thus, the volcanic rocks of the Woodstock area probably represent remnants either of the Ordovician arc or the back-arc basin. The calc-alkalic volcanism of Ordovician age in Grand Pitch and Bronson Hill in New England (Loiselle, 1985; Keppie, 1989) might be an extension of this volcanic belt.

The tectonostratigraphic subdivision of New Brunswick is usually compared with that of Newfoundland. Rast et al. (1976) have correlated the Miramichi Terrane with the Gander Zone. However, due to the absence of the Ordovician volcanic sequences and black shales in the Gander Zone, Fyffe (1976) disagreed with such a comparison. The stratigraphy of the upper part of the Tetagouche Group better correlates with the Dunnage Zone (Fyffe, 1982; van Staal, 1987). The Ordovician sequences of the Dunnage Zone include volcanic arc suites (e.g., Strong, 1977; Swinden and Thorpe, 1984) as well as within-plate basalts and MORB (e.g., Jenner and Fryer, 1980; Wasowski and Jacobi, 1985) similar to those of the Tetagouche Group.

\section{ACKNOWLEDGEMENTS}

The study was supported by the Natural Sciences and Engineering Research Council of Canada (operating grant A3782). Thanks are extended to L.R. Fyffe and J.D. Keppie for critical comments on an earlier version of this manuscript and $P$. Swinney for help with field work. The helpful comments of S. Barr, J. Winchester and J.G. Spray are very much appreciated.
ARTH, J.G. 1976. Behavior of trace elements during magmatic processes: A summary of theoretical models and their application. Journal of Research, U.S. Geological Survey, 4, pp. 41-47.

BACON, C.R., DUFFIELD, W.A., and NAKAMURA, K. 1980. Distribution of Quatemary rhyolite domes of the Coso Range, California: Implications for the extent of the geothermal anomaly. Journal of Geophysical Research, 85, pp. 2425-2433.

COMPSTON, W. and CHAPPELL, B.W. 1979. Strontium isotopic evolution of granitoid source rocks. In The Earth. Edited by M.W. McElhinney. Academic Press, London, pp. 377-424.

CONDIE, K.C. 1982. Archean andesites. In Andesites: Orogenic Andesites and Related Rocks. Edited by R.S. Thorpe. John Wiley and Sons, Heidelberg, pp. 353-370.

CRECRAFT, H.R., NASH, W.P., and EVANS, S.H. 1981. Late Cenozoic volcanism at Twin Peaks, Utah: geology and petrology. Journal of Geophysical Research, 86, pp. 10303-10320.

CROW, C. and CONDIE, K.C. 1987. Geochemistry and origin of Late Archean volcanic rocks from the Rhenosterhoek Formation, Dominion Group, South Africa. Precambrian Research, 37, pp. 217-229.

CULLERS, R.L., KOCH, R.J., and BICKFORD, M.W. 1981. Chemical evolution of magmas in the Proterozoic terrane of the St. Francois Mountains, Southeastern Missouri. 2. Trace element data. Joumal of Geophysical Research, 86, pp. 10388-10401.

DOSTAL, J., BARAGAR, W.R.A., and DUPUY, C. 1986. Petrogenesis of the Natkusiak continental basalts, Victoria Island, Northwest Territories, Canada. Canadian Joumal of Earth Sciences, 23, pp. 622-632.

DOSTAL, J., DUPUY,C., and COULON,C. 1982. Cainozoic andesitic rocks of Sardinia (Italy). In Andesites: Orogenic Andesites and Related Rocks. Edited by R.S. Thorpe. John Wiley and Sons, Heidelberg, pp. 353-370.

EWART, A. 1979. A review of the mineralogy and chemistry of Tertiary-Recent dacitic, latitic, rhyolitic and related salic volcanic rocks. In Trondhjemites, Dacites and Related Rocks. Edited by F. Barker. Elsevier Scientific Publishing, Amsterdam, pp. 13-121.

2. 1982. The mineralogy and petrology of Tertiary-Recent orogenic volcanic rocks: with special reference to the andesiticbasaltic compositional range. In Andesites: Orogenic Andesites and Related Rocks. Edited by R.S. Thorpe. John Wiley and Sons, New York, New York, pp. 25-95.

FYFFE, L.R. 1976. Correlation of geology in the southeastern and northern parts of the Mir amichi Zone. In The 139th Annual Report, New Brunswick Department of Natural Resources, pp. 137-141. - 1982. Taconian and Acadian structural trends in central and northern New Brunswick. In Major Structural Zones and Faults of the Northern Appalachians. Edited by P. St-Julien and J. Beland. Geological Association of Canada, Special Paper 24, pp. 117-129.

FYFFE, L.R. and FRICKER, A. 1987. Tectonostratigraphic terrane analysis of New Brunswick. Maritime Sediments and Atlantic Geology, 23, pp. 113-122.

FYFFE, L.R., BARR, S.M., and BEVIER, M.L. 1988. Origin and U$\mathrm{Pb}$ geochronology of amphibolite-facies metamorphic rocks, Miramichi Highlands, New Brunswick. Canadian Joumal of Earth Sciences, 25, pp. 1674-1686.

FYFFE, L.R., FORBES, W.H., and RIVA, J. 1983. Graptolites from the Benton area of west central New Brunswick and their regional significance. Maritime Sediments and Atlantic Geology, 17, pp. 23-26.

GILL, J.B. 1981. Orogenic Andesites and Plate Tectonics. Springer Verlag, Heidelberg, $390 \mathrm{p}$.

HATCH, N.L., Jr. 1982. The Taconian Line in westem New England 
and its implications to Paleozoic tectonic history. In Major Structural Zones and Faults of the Northern Appalachians. Edited by P. St-Julien and J. Beland. Geological Association of Canada, Special Paper 24, pp. 67-85.

HELMSTAEDT, H. 1971. Structual geology of Portage Lakes area, Bathurst-Newcastle district, New Brunswick. Geological Survey of Canada, Paper 70-28, 52 p.

HENDERSON, P. 1984. General geochemical properties and abundances of the rare earth elements. In Rare Earth Element Geochemistry. Edited by P. Henderson. Elsevier, Amsterdam, pp. 1-32.

HICKEY, R.L., GERLACH, D.C., and FREY, F.A. 1984. Chemical variations in volcanic rocks from central-south Chile $\left(33-42^{\circ} \mathrm{S}\right)$. In Andean Magmatism: Chemical and Isotopic Constraints. Edited by R.S. Harmon and B.A. Barreiro. Shiva Publishing, Cheshire, United Kingdom, pp. 72-95.

HILDRETH, W. and MOORBATH, S. 1988. Crustal contributions to arc magmatism in the Andes of Central Chile. Contributions to Mineralogy and Petrology, 98, pp. 455-489.

IZETT, G.A. 1981. Volcanic ash beds: Recorders of Upper Cenozoic silicic pyroclastic volcanism in the Western United States. Joumal of Geophysical Research, 86, pp. 10200-10222.

JENNER, G.A. and FRYER, B.J. 1980. Geochemistry of the Upper Snooks Arm Group basalts, Burlington Peninsula, Newfoundland: evidence against formation in an island arc. Canadian Journal of Earth Sciences, 17, pp. 888-900.

KENNEDY, D.J., BARNES, C.R., and UYENO, T.T. 1979. A Middle Ordovician conodont faunule from the Tetagouche Group, Camel Back Mountain, New Brunswick. Canadian Journal of Earth Sciences, 16, pp. 540-551.

KEPPIE, J.D. 1989. Northern Appalachian terranes and their accretionary history. Geological Society of America, Special Paper 230, pp. 159-192.

LETERRIER, J., MAURY, R.C., THONON, P., GIRARD, D., and MARCHAL, M. 1982. Clinopyroxene composition as a method of identification of the magmatic affinities of paleovolcanic series. Earth and Planetary Science Letters, 59, pp. 138-154.

LOISELLE, M.C. 1985. Bedrock geologic map of Maine. Maine Geological Survey, scale 1:500,000.

MIYASHIRO, A. 1974. Volcanic rock series in island arcs and active continental margins. American Journal of Science, 274, pp. 321 355.

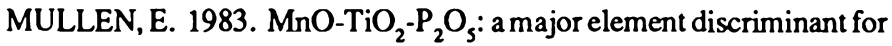
basaltic rocks of ocean environment and its implications for petrogenesis. Earth and Planetary Science Letters, 65, pp. 41-58.

NEUMAN, R.B. 1968. Paleogeographic implications of Ordovician shelly fossils in the Magog Belt of the northern Appalachians region. In Studies of Appalachian Geology-Northern and Maritime. Edited by E.-An.Zen, W.S. White, J.B. Hadley, and J.B. Thompson. Interscience, New York, New York, pp. 35-48.

-1984. Geology and paleobiology of islands in the Ordovician Iapetus Ocean: review and implications. Geological Society of America Bulletin, 95, pp. 1188-1201.

NOWLAN, G.S. 1981. Some Ordovician conodont faunules from the Miramichi Anticlinorium, New Brunswick. Geological Survey of Canada, Bulletin 345 .

OKAMURA, S. 1987. Geochemical variation with time in the Cenozoic volcanic rocks of Southwest Hokkaido, Japan. Journal of Volcanology and Geothermal Research, 32, pp. 161-176.

PAJARI, G.E., RAST, N., and STRINGER, P. 1977. Paleozoic volcanicity along the Bathurst-Dalhousie geotraverse, New Brunswick and its relations to structure. In Volcanic Regimes in
Canada. Edited by W.R.A. Baragar, L.C. Coleman, and J.M. Hall. Geological Association of Canada, Special Paper 16, pp. 111-124.

PEARCE, J.A. 1982. Trace element characteristics of lavas from destructive plate boundaries. In Andesites: Orogenic Andesites and Related Rocks. Edited by R.S.Thorpe. John Wiley and Sons, New York, New York, pp. 525-548.

1983. Role of the sub-continental lithosphere in magma genesis at active continental margins. In Continental Basalts and Mantle Xenoliths. Edited by C.J. Hawkesworth and M.J. Norry. Shiva Publishing, Cheshire, United Kingdom, pp. 230-249.

PEARCE, J.A. and CANN, J.R. 1973. Tectonic setting of basic volcanic rocks determined using trace element analysis. Earth and Planetary Science Letters, 19, pp. 290-300.

PEARCE, T.H., GORMAN, B.E., and BIRKETT, T.C. 1977. The relationship between major element chemistry and tectonic environment of basic and intermediate volcanic rocks. Earth and Planetary Science Letters, 36, pp. 121-132.

PEARCE, T.H., STIMAC, J., and DROBE, J. 1988. Why are major elements as effective as trace elements in diagnosing volcanic regimes? Annual Meeting of Geological Association of Canada, Programs with Abstracts, 13, p. A96.

POOLE, W.H. 1963. Geology of Hayesville, New Brunswick. Geological Survey of Canada, Map 6-1963.

RAST, N. and STRINGER, P. 1974. Recent advances and the interpretation of the geological structure of New Brunswick. Geoscience Canada, 1, pp. 15-25.

RAST, N., KENNEDY, M.J., and BLACKWOOD, R.F. 1976. Comparison of some tectonostratigraphic zones in the Appalachians of Newfoundland and New Brunswick. Canadian Journal of Earth Sciences, 13, pp. 868-875.

RODGERS, J. 1970. The tectonics of the Appalachians. WileyInterscience, New York, New York, $271 \mathrm{p}$.

ROY, D.C. and MENCHER, E. 1976. Ordovician and Silurian stratigraphy of northeastern Aroostock County, Maine. In Contributions to the Stratigraphy of New England. Edited by L.R. Page. Geological Society of America, Memoir 148, pp. 25-52.

RUTTENBERG, A.A., FYFFE, L.R., McCUTCHEON, S.R.,ST.PETER, C.J., IRRINKI, R.R., and VENUGOPAL, D.V. 1977. Evolution of pre-Carboniferous tectonostratigraphic zones in the New Brunswick Appalachians. Geoscience Canada, 4, pp. 171-181.

SHERVAIS, J.W. 1982. Ti-V plots and the petrogenesis of modem ophiolitic lavas. Earth and Planetary Science Letters, 59, pp. 101118.

SKINNER, R. 1974. Geology of Tetagouche Falls, Bathurst and Nepisiguit Falls map areas, New Brunswick. Geological Survey of Canada, Memoir 371, 133 p.

STERN, R.J. and GOTTFRIED, D. 1986. Petrogenesis of a Late Precambrian (575-600 Ma) bimodal suite in Northeast Africa. Contributions to Mineralogy and Petrology, 92, pp. 492-501.

STRONG, D.F. 1977. Volcanic regimes of the Newfoundland Appalachians. In Volcanic Regimes in Canada. Edited by W.R.A. Baragar, L.C. Coleman, and J.M. Hall. Geological Association of Canada, Special Paper 16, pp. 61-90.

SUN, S.S. 1982. Chemical composition and origin of the Earth's primitive mantle. Geochimica et Cosmochimica Acta, 46, pp. 179192.

SWINDEN, H.S. and THORPE, R.I. 1984. Variations in style of volcanism and massive sulfide deposition in Early-Middle Ordovician island arc sequences of the Newfoundland Central Mobile Belt. Economic Geology, 79, pp. 1596-1619.

TATSUMI, Y., HAMILTON, D.L., and NESBITT, R.W. 1986. Chemical characteristics of fluid phase released from a subducted litho- 
sphere and the origin of arc magmas: evidence from high pressure experiments and natural rocks. Journal of Volcanology and Geothermal Research, 29, pp. 293-309.

TAYLOR, S.R. and McLENNAN, S.M. 1985. The Continental Crust: its Composition and Evolution. Blackwell Scientific Publications, $312 \mathrm{p}$.

VAN DER PLUIJM, B.A. and VAN STAAL, C.R. 1988. Characteristics and evolution of the Central Mobile Belt, Canadian Appalachians. Journal of Geology, 96, pp. 535-547.

VAN STAAL, C.R. 1987. Tectonic setting of the Tetagouche Group in northern New Brunswick: implications for plate tectonic models of the northem Appalachians. Canadian Journal of Earth Sciences, 24, pp. 1329-1351.

VENUGOPAL, D.V. 1978. Geology of Benton-Kirkland Upper Eel River Bend. Mineral Resources Branch, New Brunswick Department of Natural Resources, Map Report 78-3, 16 p.

. 1979. Geology of Debec Junction-Gibson Millstream-Temperance Vale-Meductic Region. Mineral Resources Branch, New Brunswick Department of Natural Resources, Map Report 79-5, 36 p.

WASOWSKI, J.J. and JACOBI, R.D. 1985. Geochemistry and tectonic significance of the mafic volcanic blocks in the Dunnage melange, north central Newfoundland. Canadian Joumal of Earth Sciences, 22, pp. 1248-1256.

WATSON, E.B. and HARRISON, T.M. 1983. Zircon saturation revisited: temperature and composition effects in a variety of crustal magmas. Earth and Planetary Science Letters, 64, pp. 295 304.

WHITEHEAD, R.E.S. and GOODFELLOW, W.D. 1978. Geochemistry of volcanic rocks from the Tetagouche Group, Bathurst, New Brunswick, Canada. Canadian Journal of Earth Sciences, 15, pp. 207-219.

WINCHESTER, J.A. and FLOYD, P.A. 1977. Geochemical discrimination of different magma series and their differentiation products using immobile elements. Chemical Geology, 20, pp. 325-343.

WYLLIE, P.J. 1977. Crustal anatexis: an experimental review. Tectonophysics, 43, pp. 41-71.

WYLLIE, P.J., HUANG, W.L., STERN, C.R., and MAALOE, S. 1976. Granitic magmas: possible and impossible sources, water contents, and crystallization sequences. Canadian Journal of Earth Sciences, 18, pp. 1007-1019. 